\title{
Zaburzenia krzepnięcia spowodowane przewlekłym zatruciem rodentycydami antykoagulacyjnymi - opis przypadku i przegląd piśmiennictwa
}

\author{
Coagulation disorders caused by chronic poisoning with \\ anticoagulant rodenticides - case report and review of literature
}

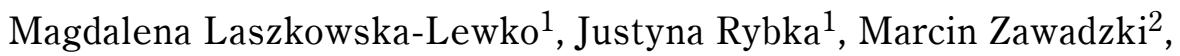 \\ Tomasz Jurek ${ }^{2}$, Tomasz Wróbel ${ }^{1}$ \\ ${ }^{1}$ Klinika Hematologii, Nowotworów Krwi i Transplantacji Szpiku, \\ Uniwersytet Medyczny im. Piastów Śląskich, Wrocław \\ ${ }^{2}$ Katedra Medycyny Sądowej, Uniwersytet Medyczny im. Piastów Śląskich, Wrocław
}

\begin{abstract}
Streszczenie
Rodentycydy antykoagulacyjne to grupa substancji stosowanych do zwalczania gryzoni. Spozycie tych zwiazków może być przyczyna cięzkich i groźnych dla życia zatruć u ludzi. Przedstawiono przypadek pacjentki z objawami przewlektej skazy krwotocznej i ze ztożonym niedoborem czynników krzepnięcia zwiazanych z dtugotrwatym stosowaniem rodentycydów.
\end{abstract}

Słowa kluczowe: superwarfaryny, rodentycydy antykoagulacyjne, witamina K, zaburzenia krzepnięcia, zatrucie

Hematologia 2017; 8, 4: 289-292

\begin{abstract}
Anticoagulant rodenticides are a group of substances used in rodent poisoning. Intake of these compounds can cause severe and life-threatening poisoning in humans. This article describes the case of patient with chronic hemorrhagic manifestations and a complex deficiency of coagulation factors caused by chronic rodenticide using.
\end{abstract}

Key words: superwarfarins, anticoagulant rodenticides, vitamin $\mathrm{K}$, coagulation disorder, intoxication

Hematologia 2017; 8, 4: 289-292

\section{Wprowadzenie}

Rodentycydy antykoagulacyjne to grupa substancji stosowanych w zwalczaniu gryzoni. Rodentycydy antykoagulacyjne II generacji (superwarfaryny) dzieli się na dwie grupy: 1) indanediony, na przykład chlorfacynon, difacynon, 2) 4-hydroksykumaryny, na przykład brodifakum, difenakum, bromandiolon i kumatetralyl [1]. W Polsce są dostępne prawie wszystkie rodentycydy II generacji, a do najczęściej stosowanych należą: Toxanox Plus $(0,5 \%$ soli sodowej warfaryny), Bros professional płyn $(0,75 \%$ soli sodowej warfaryny), Rat Killer Pasta $(0,0025 \%$ brodifakum), Bros professional kostka $(0,004 \%$ polbrodifakum), Ziarno Normix $(0,0012 \%$ brodifakum), Murin Dife saszetki, Nocurat pasta

Adres do korespondencji: Magdalena Laszkowska-Lewko, Klinika Hematologii, Nowotworów Krwi i Transplantacji Szpiku, Uniwersytet Medyczny im. Piastów Śląskich we Wrocławiu, ul. Wybrzeże Ludwika Pasteura 4, 50-367 Wrocław, tel. 7178427 54, faks 7132709 63, e-mail: Magdalena_L@op.pl 
(0,005\% difenakum), Bros granulat, kostka $(0,005 \%$ bromandiolonu), Racumin pasta $(0,037 \%$ kumatetralylu) i Ratron GR (0,0075\% chlorfacynonu) [2].

Ostre zatrucia rodentycydami antykoagulacyjnymi zawierającymi superwarfaryny dotyczą przeważnie przypadkowych zatruć zwierząt domowych. Znane są jednak przypadki świadomego i celowego spożywania tych preparatów, najczęściej w celach samobójczych. Aby zminimalizować ryzyko przypadkowego zatrucia wśród ludzi (zwłaszcza wśród dzieci) do większości preparatów dodaje się gorzkie substancje.

Poniżej przedstawiono przypadek pacjentki $z$ objawami nawracającej skazy krwotocznej i ze złożonym niedoborem czynników krzepnięcia spowodowanymi przewlekłym zażywaniem rodentycydów.

\section{Opis przypadku}

Kobietę w wieku 55 lat po raz pierwszy hospitalizowano w marcu 2013 roku na oddziale ostrych zatruć $z$ powodu podejrzenia przedawkowania paracetamolu. Po około 10 dniach stosowania paracetamolu u pacjentki wystąipiły objawy skazy pod postacią krwotoku $z$ nosa oraz krwiomoczu. $\mathrm{W}$ badaniach laboratoryjnych stwierdzono nieoznaczalny czas protrombinowy (PT, prothrombin time), wydłużony czas częściowej tromboplastyny po aktywacji (APTT, activated partial thromboplastin time) i podwyższony międzynarodowy współczynnik znormalizowany (INR, international normalized ratio), bez cech uszkodzenia wątroby. Wówczas w leczeniu zastosowano świeżo mrożone osocze (FFP, fresh frozen plasma) i witaminę K, uzyskując poprawę stanu klinicznego oraz poprawę parametrów układu krzepnięcia. Po wykluczeniu zatrucia paracetamolem oraz innymi standardowo oznaczanymi ksenobiotykami pacjentkę przekazano do kliniki hematologii. Od marca 2013 roku do maja 2014 roku była wielokrotnie hospitalizowana $\mathrm{w}$ tej klinice $z$ powodu nawracających objawów skazy krwotocznej (krwotoki $z$ nosa, wylew w obrębie języka, liczne podbiegnięcia krwawe na skórze, bóle i zawroty głowy, krwawienie z przewodu pokarmowego oraz wylewy domięśniowe). $\mathrm{W}$ badaniach laboratoryjnych stwierdzano wydłużenie APTT (maksymalnie $148 \mathrm{~s}$ ) oraz obniżone stężenia protrombiny (minimalnie $4 \%$ ), czynnika VII (minimalnie 0,1\%), czynnika IX (minimalnie $8,3 \%$ ), czynnika X (minimalnie $5,4 \%$ ) oraz białek C i S, przy prawidłowej wartości czynnika $\mathrm{V}(74,7 \%)$. W diagnostyce wykluczono obecność inhibitora czynników krzepnięcia oraz mutację genu protrom- biny. Ponadto poszerzono diagnostykę w kierunku chorób wątroby i procesów nowotworowych. Po przeprowadzeniu oceny parametrów funkcji wątroby, wykonaniu badań serologicznych, badań obrazowych (badanie radiologiczne, badanie ultrasonograficzne, tomografia komputerowa, rezonans magnetyczny, pozytonowa tomografia emisyjna, scyntygrafia kości), oznaczeniu markerów nowotworowych oraz konsultacji hepatologicznej i ginekologicznej wykluczono choroby wątroby i proces nowotworowy. Ostatecznie rozpoznano złożony zespół niedoboru czynników protrombiny i skierowano pacjentkę pod opiekę poradni hematologicznej. $Z$ powodu nawracających objawów skazy chora wymagała stosowania witaminy $\mathrm{K}$ oraz preparatów koncentratu czynników zespołu protrombiny (PCC, prothrombin complex concentrate) co 2-3 tygodnie. Ze względu na nawracający charakter schorzenia oraz odchylenia w badaniach układu krzepnięcia podlegające korekcie po zastosowaniu PCC oraz witaminy $\mathrm{K}$ wysunięto podejrzenie immunologicznego tła zaburzeń. W lipcu 2014 roku z powodu braku skuteczności dotychczasowego leczenia podjęto próbę terapii immunosupresyjnej, nie obserwując jednak ani poprawy klinicznej, ani normalizacji parametrów układu krzepnięcia. Przeprowadzono diagnostykę toksykologiczną, ale nie znaleziono żadnych cech zatrucia w standardowo wykonywanych badaniach toksykologicznych. Ponadto chorą wielokrotnie konsultowano psychiatrycznie, lecz poza labilnością emocjonalną psychiatrzy nie stwierdzali innych objawów wskazujących na odchylenia w stanie psychicznym. W grudniu 2014 roku pacjentka była hospitalizowana na oddziale intensywnej terapii (OIT) z powodu niewydolności oddechowej i masywnego krwawienia $z$ dolnych dróg oddechowych. Wymagała codziennego stosowania PCC w dawce $1200 \mathrm{j}$./dobę przez około 2 tygodnie. Wówczas, po konsultacji z lekarzem medycyny sądowej, zadecydowano o wykonaniu niestandardowych testów toksykologicznych. Krew i mocz pacjentki poddano testom na obecność superwarfaryn. Badanie wykonano metodą ultrasprawnej chromatografii cieczowej $z$ detekcją diodową (UPLC-PDA, ultrasonic liquid chromatography photodiode array) oraz chromatografii cieczowej sprzężonej $z$ tandemową spektrometrią mas (LC-MS/MS, liquid chromatography-tandem mass spectrometry). Przeprowadzone badania pozwoliły stwierdzić obecność we krwi brodifakum w stężeniu $544 \mathrm{ng} / \mathrm{ml}$. Analizując całość obrazu klinicznego choroby i przewlekle nawracające zaburzenia krzepnięcia oraz po konsultacji $z$ lekarzem medycyny sądowej u pacjentki rozpoznano prze- 
wlekłe zatrucie rodentycydami. W trakcie całego procesu diagnostycznego pacjentka zaprzeczała zażywaniu jakichkolwiek substancji toksycznych, jednak otrzymany wynik świadczył o przewlekłym doustnym zażywaniu przez chorą trutki na szczury. Pacjentka po zakończeniu hospitalizacji została skierowana pod opiekę psychiatryczną.

\section{Dyskusja}

Działanie rodentycydów antykoagulacyjnych polega na hamowaniu aktywności wątrobowej reduktazy 2-3-epoksydowej witaminy $\mathrm{K}$ i procesu funkcjonalnej $\gamma$-karboksylacji, co powoduje obniżenie stężeń czynników krzepnięcia II, VII, IX, $\mathrm{X}$ i białek C, S, M i $Z$ oraz zwiększenie stężenia 2-3-epoksydowej nieaktywnej postaci witaminy $\mathrm{K}[3,4]$. W przypadku zatruć superwarfarynami zaburzenia krzepnięcia mogą się pojawić nawet po kilku dniach i trwać przez kilka tygodni. Jest to spowodowane długotrwałą eliminacją superwarfaryn ( $\mathrm{T}_{1 / 2}$ brodifakum wynosi nawet od kilku tygodni do kilku miesięcy). Ponadto superwarfaryny cechuje większa zdolność łączenia się z miejscami wiążącymi warfarynę w hepatocytach. Działanie antykoagulacyjne można obserwować nawet wtedy, gdy brodifakum nie jest już wykrywalne w surowicy [5]. U pacjentów $z$ objawami skazy krwotocznej po zatruciu rodentycydami należy dożylnie podawać preparaty witaminy $\mathrm{K}$ pod kontrolą wartości INR. W przypadku ciężkich zatruć konieczne jest stosowanie FFP lub PCC.

Rodentycydy antykoagulacyjne mogą być niebezpieczne w przypadku spożycia w dużej ilości przez dzieci i osoby starsze lub w przypadku zażywania przewlekłego. Jednorazowe spożycie niewielkiej ilości przez zdrowych dorosłych wiąże się $z$ niewielką toksycznością [1]. W badaniu Sullivana i wsp. [6] spośród 88 osób, które uległy przypadkowemu zatruciu superwarfaryną, aż u $92 \%$ PT nie był przedłużony. Bennett i wsp. [7] wykazali, że na 26 osób, które zażyły rodentycyd, objawy kliniczne wystąpiły tylko u jednej. Natomiast King i Tran [8], w swojej pracy z 2015 roku, przenalizował 174 przypadki zatrucia rodentycydami opublikowane w bazach PubMed, Science Direct, US National Library of Medicine Toxicology Data Network i Google Scholar oraz 315951 przypadki ekspozycji zgłoszone do Amerykańskiego Stowarzyszenia Centrów Kontroli Zatruć (American Association of Poison Control Centers) z okresu 25 lat. W Stanach Zjednoczonych wśród zgłoszonych przypadków prawie $90 \%$ dotyczyło dzieci, a tylko $2 \%$ wszystkich zatruć przebiegało $z$ poważnymi powikłaniami krwotocznymi lub zakończyło się zgonem (najczęściej spowodowanym krwotokiem wewnątrzczaszkowym). Większość ekspozycji była niezamierzona, a do najczęściej zgłaszanych objawów należały krwawienia $z$ błon śluzowych oraz hematuria. Do zatruć najczęściej dochodziło drogą doustną lub oddechową [8]. Istnieje także ryzyko zatrucia zawodowego u osób zatrudnionych przy produkcji rodentycydów oraz zatrucia wtórnego po spożyciu dzikich zwierząt żerujących na terenach, gdzie stosowano środki przeciw gryzoniom [6]. Rodentycydy są również zażywane jako trucizna przez chorych z zespołem Münchausena, u których występują zaburzenia psychiczne polegające na wywoływaniu u siebie objawów somatycznych w celu wymuszenia hospitalizacji i leczenia. U chorych $z$ tym zespołem bardzo ważne są terapia polegająca na równoczesnym leczeniu zaburzeń somatycznych oraz stała opieka psychiatryczna i psychologiczna.

\section{Podsumowanie}

Przedstawiony przypadek pacjentki przewlekle zażywającej rodentycydy ilustruje znaczne trudności diagnostyczne w rozpoznawaniu zatrucia tymi substancjami. Chory, u którego podejrzewa się zaburzenia związane ze stosowaniem rodentycydów, powinien być traktowany interdyscyplinarnie, a dokonanie właściwego rozpoznania wymaga współpracy hematologa, toksykologa oraz psychiatry. Dużym problemem jest potwierdzenie zatrucia superwarfarynami, ponieważ w laboratoriach toksykologiczno-klinicznych nie oznacza się substancji aktywnych znajdujących się w rodentycydach. Wiąże się to $z$ brakiem zależności między stężeniem we krwi superwarfaryn a ich działaniem oraz trudnościami analitycznymi wynikającymi $z$ niskiej zawartości składników aktywnych w dostępnych w handlu trutkach [2, 3, 9]. Metodykę oznaczania rodentycydów dostępnych w Polsce opracował zespół Instytutu Ekspertyz Sądowych w Krakowie [10, 11]. Oznaczanie jest jednak utrudnione, ponieważ nie wszystkie laboratoria toksykologiczno-sądowe dysponują certyfikowanymi wzorcami tych związków.

\section{Piśmiennictwo}

1. Burkhart KK. Anticoagulant rodenticides. In: Ford MD, Delaney KA, Ling LJ, Erickson TWB. ed. Clinical toxicology. Saunders Company, Louis, Sydney, Toronto 2001: 848-853.

2. Zawadzki M, Magdalan J, Niedźwiedź A. Zatrucia rodentycydami antykoagulacyjnymi. Arch Med Sąd Krym. 2007; 57: 427-429.

3. Nicpoń J, Zawadzki M, Niedźwiedź A, et al. Zatrucie rodentycydami antykoagulacyjnymi u psów. Med Wet. 2007; 63(12): 1604-1606. 


\section{Hematologia 2017, tom 8, nr 4}

4. Łukasik-Głębocka M, Sein Anand J. Środki ochrony roślin. In: Pach J. ed. Zarys toksykologii klinicznej. Wydawnictwo Uniwersytetu Jagiellońskiego, Kraków 2009: 493-522.

5. Weitzel JN, Sadowski JA, Furie BC, et al. Surreptitious ingestion of a long-acting vitamin $\mathrm{K}$ antagonist/rodenticide, brodifacoum: clinical and metabolic studies of three cases. Blood. 1990; 76(12): 2555-2559, indexed in Pubmed: 2265249.

6. Sullivan MP, Dean BS, Krenzelok EP. Long-acting anticoagulant rodenticides: an evaluation of 88 cases. Vet Hum Toxicol. 1989; 31: 361-362., doi: 10.1002/9780470699010.ch18.

7. Bennett DL, Caravati EM, Veltri JC. Longacting anticoagulant ingestion: a prospective study. Vet Hum Toxicol. 1987; 27: 459-460.
8. King N, Tran MH. Long-acting anticoagulant rodenticide (superwarfarin) poisoning: a review of its historical development, epidemiology, and clinical management. Transfus Med Rev. 2015; 29(4): 250-258, doi: 10.1016/j.tmrv.2015.06.002, indexed in Pubmed: 26239439.

9. Skowronek R, Celiński R, Zawadzki M, et al. Zatrucia rodentycydami u ludzi - charakterystyka, diagnostyka i postępowanie. Lekarz. 2012; 3: 10-13.

10. Adamowicz P, Kała M. Simple HPLC method for the identification of the most popular rodenticides used in Poland. Problems of Forensic Sciences. 2005; 64: 373-381.

11. Adamowicz P, Kała M. LC-MS and LC-MS/MS determination of six anticoagulant rodenticides in blood. Problems of Forensic Sciences. 2009; 77: 53-63. 